\title{
PENDIDIKAN BELA NEGARA SEBAGAI TONGGAK PERADABAN JIWA PATRIOTISME GENERASI MUDA
}

\author{
Rahmat Wijayanto J., Marzuki \\ Program Studi Pendidikan Pancasila dan Kewarganegaraan \\ Program Pascasarjana Universitas Negeri Yogyakarta \\ rahmat.weje@gmail.com
}

\begin{abstract}
The purpose of this study was to provide an overview of state defense education carried out in Titian Teras H. Abdurrahman Sayoeti Jambi Senior High School through civic education and special curriculum. State defense education that is implemented in the school is carried out to shape the spirit and spirit of patriotime of students or young people in the face of the times and globalization. This study uses a qualitative approach. Data was obtained through interviews, and observations of teachers and students from Titian Teras H. Abdurrahaman Sayoeti Jambi Senior High School. The results showed that the state defense education implemented in Titian Teras H. Abdurrahman Sayoeti Jambi Senior High School had a function in growing and strengthening the values of patrotism in students. Education defends the country teaches about love for the homeland, the spirit of struggle, nationalism, patriotism and excellent physical endurance. The material provided includes insight into nationalism, line marching, time discipline, long march and leadership. Thus education in defense of the state has a positive contribution in shaping students who have a spirit of patriotism from an early age.
\end{abstract}

Keywords: state defense education, patriotic, patriotism, young generation.

\begin{abstract}
Abstrak: tujuan penulisanartikel ini untuk memberikan gambaran mengenai pendidikan bela negara yang dilaksanakan melalui kurikulum khusus. Kajian menggunakan pendekatan kualitatif. Pengumpulan data menggunakan tehnik wawancara, dan observasi. Hasil penelitian menunjukkan bahwa pendidikan bela negara yang diterapkan memiliki fungsi dalam menumbuhkan dan memperkuat nilai-nilai patrotisme dalam diri siswa. Pendidikan bela negara mengajarkan mengenai kecintaan pada tanah air, semangat perjuangan, nasionalisme, patriotisme dan ketahanan fisik yang prima. Materi yang diberikan antara lain yakni wawasan kebangsan, baris berbaris, disiplin waktu, long march dan kepemimpinan. Dengan demikian pendidikan bela negara mempunyai kontribusi positif dalam membentuk siswa yang memiliki semangat patriotisme sejak dini.
\end{abstract}

Kata kunci: pendidikan bela negara, patriotik, patriotisme, generasi muda.

Generasi muda yang notabene merupakan aset berharga bagi sebuah negara, harus diperhatikan keberadaannya agar negara tidak kekurangan generasi penerus dalam pembangunan. Generasi muda juga dapat dengan mudah menerima efekefek globalisasi melalui akses modernisasi dan kemajuan teknologi saat ini yang tidak bisa dielakkan oleh siapapun dalam suatu negara.

Perkembangan dunia membawa setiap bangsa dan negara harus siap untuk menghadapi segala macam resiko. Salah satunya ialah resiko yang dibawa oleh globalisasi dan modernisasi, begitu juga dengan generasi muda saat ini yang tengah hidup dalam kemajuan teknologi yang membuat seakan hidup ini tanpa ada batasan sama sekali.

Nester (2010:9) menjelaskan dalam bahwa globalisasi merupakan hasil dari kelahiran modernisasi yang digunakan untuk melakukan serangkaian revolusi baik itu di bidang ilmu pengetahuan, politik, ekonomi, dan teknologi. Dengan demikian globalisasi tidak hanya membawa dampak pada kemajuan teknologi namun juga membawa dampak pada keadaan politik, ekonomi dan teknologi.

Keselamatan suatu bangsa dan negara merupakan suatu kondisi yang harus terwujud dan 
tidak dapat ditawar apabila bangsa dan negara itu ingin bertahan hidup sebagai suatu negara. Untuk menjaga keselamatan tersebut dibutuhkanlah suatu upaya bela negara. Budiyono (2017: 55-63) menjelaskan bahwa bela negara memiliki kaitan yang sangat tinggi di era global saat ini guna memperkuat pertahananan dan keamanan bangsa Indonesia di tengah banyaknya lahir ideologiideologi asing yang tidak sesuai dengan jati diri bangsa Indonesia, dengan adanya bela negara dapat memberi masukan dan energi baru untuk memperkuat karakter bangsa Indonesia.

Winarno (2013:182) menjelaskan bela negara adalah upaya setiap warga negara Republik Indonesia terhadap ancaman, baik dari luar maupun dari dalam negeri. Untuk menjaga stabilitas dan keamanan suatu negara melalui pembelaan untuk negara, perlu juga diperhatikan kepentingan yang dibutuhkan oleh negara tersebut. Dover \& Phythian (2011: 420-444) menjelaskan bahwa dengan adanya kebutuhan atau kepentingan nasional maka mau tidak mau akan memaksa dan menyadarkan seorang warga negara untuk ikut serta dalam membela negaranya sendiri yang didasarkan dengan kepercayaan pada nilai-nilai yang ada dalam demokrasi, hukum, kebebasan berbicara, toleransi dan hak asasi manusia.

Bentuk kecintaan seorang warga negara terhadap negaranya dapat diimplementasikan dalam kegiatan bela negara. Maraknya persoalan bela negara seringkali menimbulkan kontradiksi dalam penafsirannya, pelaksanaan pendidikan bela negara merupakan langkah awal pencegahan timbulnya konflik yang dapat menciptakan perpecahan dalam suatu negara.

Terdapat hubungan antara ketahanan nasional suatu negara dan pembelaan terhadap negara. Kegiatan pembelaan negara pada dasarnya merupakan usaha dari warga negara untuk mewujudkan ketahanan nasional.

Upaya dalam pelaksanaan bela negara selanjutnya diatur dalam Undang-Undang Nomor 3 Tahun 2002 tentang Pertahanan Negara. Pada Pasal 9 ayat (1) dinyatakan bahwa "setiap warga negara berhak dan wajib ikut serta dalam upaya bela negara yang diwujudkan melalui penyelenggaraan pertahanan negara". Selanjutnya dalam Pasal 9 ayat (2) dinyatakan bahwa "keikutsertaan warga negara dalam upaya bela negara, sebagaimana dimaksud dalam ayat (1), diselenggarakan melalui, pendidikan kewarganegaraan, pelatihan dasar kemiliteran secara wajib, pengabdian sebagai Tentara Nasional Indonesia, dan pengabdian sesuai dengan profesi.

Pelaksanaan pendidikan bela negara di SMA Negeri Titian Teras H. Abdurrahman Sayoeti sendiri hanya ditujukkan kepada siswa dan siswi atau peserta didik yang sekolah di sana. Kegiatan pendidikan bela negara di SMA N Titian Teras $\mathrm{H}$. Abdurrahman Sayoeti Jambi, dilaksanakan pada hari sabtu yang bertempat di (lapangan upacara/ plasa). Kegiatan tersebut dilakukan untuk membentuk sikap disiplin siswa dengan cara berlatih baris-berbaris, dan cek kerapian ala militer. Selain kedua cara tersebut siswa juga diberikan materi mengenai napak tilas atau long march yang mana kegiatan tersebut dilaksanakan untuk menumbuhkan cinta tanah air, dan patriotisme siswa.

Pendidikan bela negara yang diajarkan melalui pendidikan kewarganegaraan di SMA Negeri Titian Teras H. Abdurrhaman Sayoeti memiliki hubungan secara langsung dengan kegiatan pendidikan bela negara yang diajarkan melalui kurikulum khusus setiap hari sabtu. Pelaksanaan pendidikan bela negara melalui pendidikan kewarganegaraan di kelas dilakukan untuk memperdalam pengetahuan siswa mengenai makna bela negara itu sendiri, sedangkan praktik nyatanya di lapangan dilakukan melalui kegiatan bela negara. Materi bela negara yang diajarkan lewat mata pelajaran pendidikan kewarganegaraan dilakukan dengan cara diskusi dan tanya jawab.

\section{METODE}

Penelitian ini menggunakan pendekatan kualitatif. Moleong (2014:6) memberi penjelasan mengenai penelitian kualitatif yakni penelitian yang bermaksud untuk memahami fenomena tentang apa yang dialami oleh subjek penelitian mislanya perilaku, persepsi, motivasi, tindakan dan lainnya, secara holistik dan dengan cara deskripsi ke dalam kata-kata (kalimat) yang ilmiah dengan menggunakan berbagai metode ilmiah. Data dalam penelitian ini didapatkan dari hasil wawancara mendalam dengan orang-orang yang terlibat langsung dalam pelaksanaan pendidikan bela negara di SMA N Titian Teras H. Abdurrahman Sayoeti Jambi. Selain wawancara, data didaptkan pula dari hasi observasi secara langsung ketika pelaksanaan pendidikan bela negara sedang 
berlangsung. Adapun narasumber dalam penelitian ini antara lain adalah kepala sekolah, wakil kepala sekolah, guru bela negara, dan siswa SMAN Titian Teras H. Abdurrahman Sayoeti Jambi.

\section{HASIL DAN PEMBAHASAN}

Derasnya arus globalisasi dan budaya barat yang masuk ke Indonesia mengakibatkan lunturnya nilai patriotisme di kalangan generasi muda. Hilangnya rasa cinta tanah air di kalangan generasi muda akan berdampak buruk untuk bangsa dan negara. Generasi muda yang anti patriotisme adalah mereka yang melakukan hal-hal yang bertentangan dengan nilai-nilai kebangsaan, norma sosial, dan agama serta yang dapat merugikan dirinya sendiri. Padahal dengan memiliki sikap patriotisme generasi muda dapat mengubah sejarah bangsa menuju lebih baik lagi. Nilai patriotisme itu bukan sekedar keberanian dan miliki nyali besar. Nilai patriotisme adalah sikap berani, pantang menyerah dan rela berkorban demi bangsa dan negara.

Pembelaan negara atau bela negara adalah tekad, sikap, dan tindakan warga negara yang teratur, menyeluruh, terpadu, berlanjut yang dilandasi oleh kecintaan pada tanah air, kesadaran berbangsa dan bernegara Indonesia. Keyakinan akan kesaktian Pancasila sebagai ideologi negara, dan kerelaan untuk berkorban guna menghadapi setiap ancaman baik luar maupun dalam n e g e r yang membahayakan kemerdekaan dan kedaulatan negara, kesatuan dan persatuan bangsa, keutuhan wilayah, yurisdiksi nasional, nilainilai Pancasila, dan UUD 1945.

Tiap-tiap warga negara berhak dan wajib ikut serta dalam usaha pembelaan negara dan syaratsyarat tentang pembelaan diatur dengan undangundang. Kesadaran bela negara itu hakikatnya kesediaan berbakti pada negara dan kesediaan berkorban membela negara. Dimensi dalam bela negara itu sangat luas, dari yang paling halus, hingga yang paling keras. Mulai dari hubungan baik sesama warga negara sampai bersama-sama menangkal ancaman nyata musuh bersenjata. Tercakup di dalamnya adalah bersikap dan berbuat yang terbaik bagi bangsa dan negara.

Kegiatan pendidikan bela negara di SMA N Titian Teras H. Abdurrahman Sayoeti Jambi, rutin dilaksanakan pada hari sabtu yang bertempat di lapangan upacara. Kegiatan tersebut dilakukan untuk membentuk sikap disiplin siswa dengan erlatih baris-berbaris, dan cek kerapian ala militer. Selain kedua cara tersebut siswa juga diberikan materi mengenai napak tilas atau long march yang mana kegiatan tersebut dilaksanakan untuk menumbuhkan rasa nasionalisme, cinta tanah air, dan patriotisme siswa sejak dini.

Selain itu, pendidikan bela negara juga diinternalisasikan dalam mata pelajaran PPKn, pelaksanaan pendidikan bela negara melalui pembelajaran PPKn dilakukan untuk memperdalam pengetahuan siswa mengenai makna bela negara, sedangkan praktik nyatanya di lapangan dilakukan melalui kegiatan bela negara. Materi bela negara yang diajarkan lewat mata pelajaran PKn dilakukan dengan cara diskusi dan tanya jawab. Pelaksanaan pendidikan bela negara yang diinternalisasikan dalam mata pelajaran PPKn di kelas diajarkan melalui materi integrasi nasional dan materi bela negara.

Pendidikan bela negara yang dilakukan dapat menumbuhkan lima nilai dasar yang terkandung dalam bela negara, yakni rasa cinta pada tanah air, rela berkorban, sadar berbangsa dan bernegara, meyakini Pancasila sebagai ideologi negara, serta memiliki kemampuan awal bela negara secara fisik dan nonfisik yang dapat diajarkan melalui antara lain latihan baris berbaris (Rahman, 2015:1).

Penanaman sikap patriotisme kepada siswa dapat dilakukan dengan cara melaksanakan pendidikan bela negara, karena dari pendidikan bela negara tersebut siswa dapat mengetahui bagaiamana cara untuk menjadi seorang yang patriot. Dari hasil pengamatan 6 Februari 2018 di lapangan, pelaksanaan upacara bendera berjalan dengan khidmat dan siswa dengan penuh kerelaan dan keikhlasan mengikuti proses upacara dari awal hingga akhir. Selain itu, penanaman sikap patriotisme juga dilakukan dengancara melantunkan lagu-lagu kebangsaan atau perjuangan setiap sore di area atau lingkungan asrama ketika siswa pulang dari sekolah.

Upaya bela negara adalah kegiatan yang dilakukan oleh setiap warganegara sebagai penunaian hak dan kewajiban dalam rangka penyelenggraan pertahanan negara. Kegiatan ini untuk mencapai sasararan yang diharapkan sesuai dengan Pasal 30 UUD 1945 (Wirojoedo, 1983: 126). Namun untuk melakukan upaya pembelaan negara perlu dilandasi nilai-nilai kebajikan dalam bela negara. Nilai-nilai tersebutlah yang nantinya akan menjadi landasan dalam bersikap dan 
menjalankan upaya bela negara untuk negara Republik Indonesia khususnya bagi generasi muda.Secara sederhana nilai dimaknai nilai merupakan segala sesuatu yang dianggap berharga atau penting. Nilai yang melandasi pelaksanaan bela negara meliputi rasa cinta tanah air, rela berkorban, sadar berbangsa dan bernegara, meyakini Pancasila sebagai ideologi negara, serta memiliki kemampuan awal bela negara. Beberapa nilai yang terkandung dalam bela negara yakni, nilai kejuangan, nilai berbangsa dan bernegara serta bermasyarakat, nilai kewaspadaan akan kelangsungan hidup negara Indonesia, dan nilainilai patriotisme.

Pendidikan bela negara yang bersifat aplikatif tentunya dapat dengan langsung memberikan pengaruh kepada siswa terkait kemampuan atau sikap patriotisme. Selain dengan adanya kegiatan yang bersifat aplikatif, kegiatan penanaman pengetahuan atau pemberian materi juga dilakukan untuk menciptakan siswa yang memiliki sifat patriotisme.Hal ini sejalan dengan karakteristik dari sikap patriotisme sendiri seperti cinta tanah air, rela berkorban untuk kepentingan bangsa dan negara, menjunjung tinggi persatuan dan kesatuan serta keselamatan bangsa dan negara di atas kepentingan pribadi dan golongan (Putri, dkk, 2015:3).

Bagi seorang pelajar maka sikap patriotisme yang harus mereka miliki adalah, semangat juang yang ditunjukkan melalui semangat belajar yang baik dan benar. Kemudian cinta tanah air dan mengingat jasa para pahlawan yang telah memperjuangkan kemerdekaan Indonesia dan melanjutkan perjuangan para pahlawan bangsa dengan belajar yang tekun dan rajin sehingga mampu mengharumkan nama bangsa.

Bentuk sikap patriotisme siswa SMA Negeri Tititian Teras H.A.S Jambi tercermin dari kegiatan bela negara, partisipasi dalam mengikuti kegiatan upacara bendera,bertanggung jawab pada kegiatan apel pagi dan siang, peduli akan sesama teman, saling bertoleransi akan perbedaan yang ada, tanggung jawab akan pengumpulan tugas, serta ketaatan dalam beribadah. Penanaman sikap patriotisme pada siswa SMAN Titian Teras H.A.S Jambi sangat dibutuhkan karena selain sebagai media untuk menumbuhkan rasa peduli atau cinta pada negaranya, juga sebagai salah satu upaya dalam mengembangkan semangat perjuangan mereka. Perjuangan seorang pelajar atau peserta didik ialah dengan belajar sungguh-sungguh, dan juga mereka harus dapat menghargai jasa para pahlawan bangsa dalam untuk merebut serta mempertahankan kemerdekaan dari para penjajah.

Pentingnya pemahaman materi pertahanan dan keamanan dalam membentuk sikap patriotisme generasi muda disebabkan patriotisme merupakan wujud sikap cinta tanah air. Patriotisme membawa kemakmuran dan kemajuan untuk mencapai citacita bangsa, khususnya di bidang pendidikan. Salah satu tujuan yang hendak dicapai melalui pendidikan, antara lain pendidikan harus mampu menumbuhkan rasa nasionalisme dan patriotisme, mempertebal semangat kebangsaan, dan memperkokoh rasa kesetiakawanan. Mengingat karakteristik dari sikap patriotisme itu sendiri seperti cinta tanah air, rela berkorban untuk kepentingan bangsa dan negara, menjunjung tinggi persatuan dan kesatuan, serta keselamatan bangsa dan negara di atas kepentingan pribadi dan golongan (Putri, dkk, 2015:3). Tujuan pembentukan sikap patritotisme pada diri siswa SMA Negeri Titian Teras H.A.S Jambimelalui pendidikan bela negara di rasa cukup optimal dan sudah berjalan dengan baik.

Sejalan dengan hal tersebut, untuk menindaklanjuti pentingnya penanaman nilai-nilai patriotisme, patriotisme memiliki makna taat setia yang amat sangat terhadap nilai-nilai budaya nasional tanpa sembarang mengkritik, dan pada waktu yang sama merasakan negara sendiri jauh lebih baik dari pada negara lain. Maksud dari nilai patriotisme sering kali dianggap sebagai suatu kesetiaan dan kecintaan terhadap bangsa dan negara. Karena nilai patriotisme merupakan unsur yang menguatkan perasaan, sikap dan pandangan serta nilai terhadap negara. Patriotisme dikaitkan dengan semangat, perasaan, sikap, dan idealisme yang menyentuh soal-soal kebangsaan, kenegaraan, tanggung jawab, perjuangan, pengorbanan, kecintaan, kesetiaan, ketahanan diri dan sumbangan warga negara terhadap negara, bangsa dan agama (Seman, 2009: 29). Tugas seorang pelajar adalah dengan belajar sungguhsungguh

Sebagai salah satu media untuk membentuk generasi muda yang memiliki semangat dan patriotisme, pendidikan bela negara yang diterapkan di SMA Negeri Titian Teras H. Abdurrahaman Sayoeti sangat memengang teguh visi, misi dan tujuan sekolah. Dengan demikian pelaksanaan pendidikan bela negara dilakukan dalam upaya untuk membentuk siswa atau 
generasi muda atau kader pembangunan bangsa yang berkualitas tinggi, yang mempunyai jiwa patriotisme yang tinggi.

Balabanis et al (2001:160) menjelaskan bahwa "Patriotism refers to strong feelings of attachment and loyalty to one's own country without the corresponding hostility towards other nations" dengan kata lain bahwa patriotisme mengacu pada perasaan keterikatan seseorang dan loyalitas yang kuat ke pada negaranya sendiri tanpa adanya hubungan dengan permusuhan akan negara lain. Dengan demikian, jelas patriotisme ialah mengenai kecintaan seorang warga negara kepada negaranya dengan rela memberikan apa saja yang ia miliki karena loyalitas tinggi yang dia miliki demi keberlangsungan hidup negaranya.

Untuk menanggapi penjelasan di atas, tujuan pendidikan bela negara menurut Menteri Pertahanan Indonesia dalam laman web kemhan.go.id sebagai salah satu program dalam mendukung pembangunan bangsa dan negara Indonesia yang besar, terkhusus dalam pembangunan kekuatan petahanan negara. Nilainilai yang tekandung dalam pendidikan bela negara hendaknya betul-betul dihayati untuk menumbuhkan rasa cinta tanah air, sadar berbangsa dan bernegara, yakin pada Pancasila sebagai falsafah dan dasar negara, dan rela berkorban untuk bangsa dan negara (Hidayat \& Widjanarko, 2008: 322).Selain itu pendidikan bela negara juga sebagai wadah untuk menumbuhkan semangat nasionalisme dan patriotisme generasi muda Indonesia pada khususnya. Bela negara merupakan benteng bagi negara dalam

\section{DAFTAR RUJUKAN}

Balabanis, G., Diamantopouluos, A., Mueller, R. D., \& Melewar, T. C. 2001. The impact of nationalism, patriotism, and internationalism on consumer ethnocentric tendencies. Journal of International Business Studies. 32(1), 157-175.

Budiyono. 2017. Memperkokoh idiologi negara pancasila melalui bela negara. Citizenship Jurnal Pendidikan Pancasila dan Kewarganegaraan. 5(1) 55-63.

Dover, R., \& Phythian, M. 2011. Lost over Libya: the 2010 strategic defence and security review - an obituary. Journal Defence Studies, 11(3), 420-444. https://doi.org/10.1080/ menyelamatkan keberlangsungan hidup berbangsa dan bernegara.

\section{SIMPULAN}

Kegiatan pendidikan bela negara di SMA Negeri Titian Teras H. Abdurrahman Sayoeti Jambi, dilaksanakan pada hari sabtu yang bertempat di (lapangan upacara/plasa). Kegiatan tersebut dilakukan untuk membentuk sikap disiplin siswa dengan cara berlatih baris-berbaris, dan cek kerapian ala militer. Selain kedua cara tersebut siswa juga diberikan materi mengenai napak tilas atau long march yang mana kegiatan tersebut dilaksanakan untuk menumbuhkan rasa nasioanlisme, cinta tanah air, dan patriotisme siswa sejak dini.

Pendidikan bela negara di SMANegeri Titian Teras H. Abdurrahman Sayoeti Jambibersifat aplikatif. Sehingga dapat dengan langsung memberikan pengaruh kepada siswa terkait pembentukan sikap patriotisme. Selain dengan adanya kegiatan yang bersifat aplikatif, kegiatan penanaman pengetahuan atau pemberian materi juga dilakukan untuk menciptakan siswa yang memiliki sifat patriotisme. Pelaksanaan pendidikan bela negara merupakan sarana penunjang dalam menumbuhkan sikap patriotisme pada diri peserta didik. Melalui kegiatan bela negara yang dilaksanakan di SMA Negeri Titian Teras $\mathrm{H}$. Abdurrahman Sayoeti Jambimemiliki peranan sebagai penguatan dan landasan jiwa patriotisme bagi siswa dalam bersikap ataupun berprilaku.

\subsection{1 .630175}

Hidayat, K., \& Widjanarko, P. 2008. Reinventing Indonesia: Menemukan kembali masa depan Indonesia. Jakarta: Mizan.

Moleong, L. J. (2014). Metodologi penelitian kualitatif. Bandung: Remaja Rosdakarya.

Nester, W. R. 2010. Globalization - A short history of the modern world. New York: Palgrave Macmillan.

Putri, D., Holilullah., \& Yanzi, H. 2015. Hubungan tingkat pemahaman konsep pertahanan dan keamanan bangsa Indonesia dengan sikap patriotisme. Jurnal Kultur Demokrasi, 3(1), $1-13$. 
Rahman, Z. 2015. Program Bela Negara Sebagai Perwujudan Hak dan Kewajiban Warga negara alam Penyelenggaraan Pertahanan Negara. Jurnal Rechtsvinding Online BPHN.

Republik Indonesia. 1982. Undang-Undang RI Nomor 20, Tahun 1982, tentang KetentuanKetentuan Pokok Pertahanan Keamanan Negara Republik Indonesia.

Republik Indonesia. 2002. Undang-Undang RI Nomor 3, Tahun 2002, tentang Pertahanan Negara.
Seman, A. A. B. 2009. Pemupukan patriotisme melalui pendidikan multikultural dalam pendidikan sejarah di Malaysia. Jurnal IlmuIlmu Sejarah, Budaya dan Sosial, 1(2), 2849

Winarno. 2013. Paragdigma baru pendidikan kewarganegaraan (panduan kuliah di perguruan tinggi). Jakarta: PT Bumi Aksara. 